\title{
Effect of potassium and calcium upon the yield and fruit quality of Cucumis melo
}

\author{
Bouzo, C. A., Céccoli, G. and Muñoz, F.
}

\begin{abstract}
SUMMARY
The aim of this work was to study the effect of potassium and calcium in combination with nitrogen upon the yield and fruit quality of outdoor-grown melon (Cucumis melo L.). Two experiments were simultaneously performed through the use of two cultivars: 'Honey Dew Green Flesh' (Inodorus group) and 'Sivan' (Charentais group). A completely randomized experimental design was used with nine treatments resulting in a factorial arrangement of $3 \times 3$ due to the use of three doses of $\mathrm{K}$ and three doses of $\mathrm{Ca}$. Doses were administered through fertigation with the injection of the fertilizers into a drip irrigation system, expressed as follows in relation to $\mathrm{N}: \mathrm{N}: \mathrm{K}(1.8: 1.0-1.0: 1.0-0.0: 1.0)$ and Ca: $\mathrm{N}$ (2.0:1.0 - 1.0:1.0 - 0.0:1.0). Fertilization with nitrogen and phosphorus was the same in all treatments, through the application of an equivalent of $160 \mathrm{~kg} \mathrm{ha}^{-1}$ of $\mathrm{N}$ and $45 \mathrm{~kg} \mathrm{ha}^{-1}$ of P. Yield $\left(\mathrm{Mg} \mathrm{ha}^{-1}\right)$ was measured as well as fruit quality attributes: firmness $(\mathrm{kg})$; pulp or mesocarp thickness $(\mathrm{mm})$ and rind thickness $(\mathrm{mm})$; and total soluble solids (\%). Differences were observed between the two varieties. The application of $\mathrm{K}$ showed the greatest effect on the quality and yield of the harvested fruit. However, this effect was not observed with Ca.
\end{abstract}

Keywords: Cucumis melo L., plant nutrition, firmness, total soluble solids.

Bouzo, C. A., Céccoli, G. y Muñoz, F., 2018. Efecto del potasio y del calcio sobre el rendimiento y la calidad de Cucumis melo. Agriscientia 35: 25-33

\section{RESUMEN}

Este trabajo tuvo como objetivo evaluar el efecto del potasio y el calcio con relación al nitrógeno sobre el rendimiento y la calidad de melón (Cucumis melo L.) cultivado al aire libre. Se evaluaron dos cultivares de melón: 'Honey Dew Green Flesh' del grupo Inodorus y 'Sivan' del grupo Charentais. El diseño experimental utilizado fue completamente al azar, mediante un arreglo factorial de $3 \times 3$, totalizando nueve tratamientos, los que estuvieron constituidos por las combinaciones de tres dosis de $\mathrm{K}$ y tres de $\mathrm{Ca}$, suministrado mediante fertirriego y expresadas con relación al nitrógeno, K:N (1,8:1,0 - 1,0:1,0 - 0,0- 
1,0) y Ca:N (2,0:1,0 - 1,0:1,0 - 0,0:1,0). La fertilización con nitrógeno y fósforo fue la misma en todos los tratamientos, siendo de $160 \mathrm{~kg} \mathrm{ha}^{-1}$ de $\mathrm{N}$ y $45 \mathrm{~kg} \mathrm{ha}^{-1}$ de $\mathrm{P}$. Se midieron el rendimento $\left(\mathrm{Mg} \mathrm{ha}^{-1}\right)$ y la calidad de los frutos mediante la firmeza $(\mathrm{kg})$, espesor de pulpa o mesocarpo $(\mathrm{mm})$ y cáscara $(\mathrm{mm})$, y la concentración de sólidos solubles totales (\%). Se observaron diferencias entre los dos cultivares analizados. La utilización de K presentó un gran efecto sobre la calidad y el rendimiento. Sin embargo, esto mismo no pudo ser observado mediante la aplicación de Ca.

Palabras clave: Cucumis melo L., nutrición mineral, firmeza, sólidos solubles totales.

Bouzo, C. A., Céccoli, G. and Muñoz, F.: Universidad Nacional del Litoral, Facultad de Ciencias Agrarias, Laboratorio de Investigaciones Multidisciplinario en Fisiología y Biología Molecular Vegetal (LIFIBVE), Kreder 2805. C.P. 3080. Esperanza, Santa Fe. Correspondence to: cbouzo@arnet.com.ar

\section{INTRODUCTION}

Potassium ( $\mathrm{K}$ ) and calcium $(\mathrm{Ca})$ as well as nitrogen $(\mathrm{N})$ are the main nutrients absorbed from the soil solution. The physiological functions of $\mathrm{K}$ in plants are numerous, including enzymatic activation, osmoregulation, and synthesis of carbohydrates, nucleic acids and proteins (Demiral and Köseoglu, 2005). The $\mathrm{Ca}$, in its turn, has important functions in plant nutrition, which range from being a stabilizing element of the cell wall to becoming a secondary messenger in the cytoplasm (Le Bot, Pilbeam and Kirkby, 1994). $\mathrm{N}$ is related to these elements and is able to generate induced $\mathrm{K}$ and $\mathrm{Ca}$ deficiency, especially the latter one, depending on the $\mathrm{N}$ supply to the plant. Thus, a high fertilization with $\mathrm{N}$ causes an excessive vegetative growth and could enhance Ca deficiency in the fruit (Le Bot et al., 1994). However, Ca is not only affected by the amount of $\mathrm{N}$ but also by the type of nitrogen fertilizer. When a nitric source $\left(\mathrm{N}_{-} \mathrm{NO}_{3}{ }^{-}\right)$is used for fertilizing, Ca uptake is stimulated, in comparison with fertilization with an ammonium source $\left(\mathrm{N}_{-} \mathrm{NH}_{4}{ }^{+}\right)$ (Le Bot et al., 1994).

Previous studies in melon (Cucumis melo L.) with respect to fertilization with $\mathrm{N}, \mathrm{P}$ and $\mathrm{K}$ and their effect on foliar pigments revealed that the chlorophyll content was related to treatments with $\mathrm{N}$ and $\mathrm{K}$ due to a slight Mg induced deficiency (Valenzuela, Sanchez and Romero, 1994). When experiments were performed with different nitrogen doses and soil moisture levels, it could be observed that with $10 \mathrm{kPa}$ of water potential and $160 \mathrm{~kg} \mathrm{ha}^{-1}$ of $\mathrm{N}$, it was possible to achieve a yield close to $80 \mathrm{Mg} \mathrm{ha}^{-1}$ using a charentais variety (Cigales-Rivero, Pérez-Zamora and Pérez-Castro, 2006). Given the importance of
$\mathrm{Ca}$ and $\mathrm{K}$ on the crop nutrition, and considering not only productivity but also product quality, there is still uncertainty with respect to the nutritional management for outdoor production. In this vein, Hochmuth (1992) established different critical levels expressed in foliar concentrations (\%) for mineral nutrients of this species. These results revealed that for concentrations considered adequate, the ratios of $\mathrm{K}: \mathrm{N}$ and $\mathrm{Ca}: \mathrm{N}$ would be 1.5:1.0 and 1.0:1.0, respectively. From the measurement of the total nutrients uptake in a greenhouse-grown melon crop Rincón Sánchez, Sáez Sironi, Pérez Crespo and Madrid (1998) found K:N and Ca:N ratios of 2.0:1.0 and 0.8:1.0, respectively. In a procedure proposed to predict the need for manure for melon, a K:N ratio of 1.3:1.0 was found, without considering Ca (Bouzo, Astegiano and Favaro, 2003). These ratios are general for the crop. However, it should be taken into account that for an optimal nutritional management, these ratios should be modified according to the phenological stage of the crop (Bar-Yosef, 1999).

Even though nutrient relations are important to define the effect of the different relative doses upon yield and fruit quality of melon, in Argentina there are relatively few experimental works. Experiments carried in Brazil with different doses of $\mathrm{N}$ and $\mathrm{K}$ allowed determining that the increase of $\mathrm{N}$ decreased the pulp firmness even though it favoured the increase in the number and total mass of fruits, being this effect independent of the doses of K (Silva, Rodrigues, Medeiros, Aquino and Silva, 2007) However, different results were found by Chaves et al., (2014). In this work, the fruits submitted to treatment with doses of 666 $\mathrm{kg} \mathrm{ha}^{-1}$ of $\mathrm{N}$ and $\mathrm{O} \mathrm{kg} \mathrm{ha-1}$ of $\mathrm{K}_{2} \mathrm{O}$ showed higher 
firmness than fruits treated with doses of $38 \mathrm{~kg}$ $\mathrm{ha}^{-1}$ of $\mathrm{N}$ and $83 \mathrm{~kg} \mathrm{ha}^{-1}$ of $\mathrm{K}_{2} \mathrm{O}$. Other authors observed that nitrogen has no influence upon the fruit quality attributes such as soluble solids concentration and pulp firmness (Monteiro, Costa, Silva and Figueiredo, 2003). These results are not in agreement with those of Faria, Costa, Pinto, Brito and Soares (2000) who observed an increment in the concentration of soluble solids. Similarly, $\mathrm{K}$ may increase soluble solids content (Oliveira, Laura, Biscola, Faver and Dornas, 2003) or have no influence at all (Srinivas and Prabhakar, 1984). Purquerio and Cecílio Filho (2005) have determined a slight increase on total acidity due to the increase of nitrogen concentration in nutrient solution, without any significant effect on total soluble solids. Under protected environment other authors found that increasing $\mathrm{N}$ rates promoted lineal increment in the mesocarp thickness, total soluble solids and titratable acidity and lineal decrease in maturation index (Queiroga, Puiatti, Fontes, Cecon and Finger, 2007). Recently, using different doses of $N$ and $\mathrm{K}$ allowed determining positive correlations with yield in a charentais melon crop in greenhouse (Contreras, Plaza, Lao and Segura, 2012).

These previous studies are evidence of the doubts that still persist about the nutritional management of this crop, especially concerning the mutual relationships between the main nutrients. These doubts are locally enhanced by the little research work on this topic in Argentina. Therefore, the aim of the present study was to study the effect of $\mathrm{K}$ and $\mathrm{Ca}$ in combination with $\mathrm{N}$ upon the yield and fruit quality of outdoor-grown melon.

\section{MATERIAL AND METHODS}

\section{Characterization of the experiments}

The field work was performed in the "Campo Experimental de Cultivos Intensivos y Forestales (CECIF)" (Intensive Farming and Agroforestry Experimental Field), Universidad Nacional del Litoral, UNL, (31 $27^{\circ} \mathrm{S}$; $\left.60^{\circ} 56^{\prime} \mathrm{W}\right)$. Two experiments were simultaneously performed through the use of two cultivars: 'Honey Dew Green Flesh' (Inodorus group) and 'Sivan' (Charentais group). The sowing was carried out on October 16 with plug trays of $100 \mathrm{~cm}^{3}$ volume per cell and the transplant was performed on November 29, 2014. The substrate employed was a commercial one composed of compost ( $80 \% \mathrm{v}: \mathrm{v})$ and perlite (20\% v:v) enriched with slow-release fertilizers. The final density of the plants was equivalent to 11,000 plant ha $^{-1}$, and was achieved by transplanting in rows with a separation of $1.5 \mathrm{~m}$ between rows and $0.6 \mathrm{~m}$ between plants. In the rows, the soil was previously covered with black polyethylene $30 \mu \mathrm{m}$ thick and $0.60 \mathrm{~m}$ wide, with the compensated drip tape underneath for fertigation. In this way, localized fertigation was carried out with drippers separated by $0.20 \mathrm{~m}$ and a unitary flow of $2 \mathrm{~L} \mathrm{~h}^{-1}$. Fertilization with nitrogen and phosphorus in all the treatments was the same, with a total amount equivalent to $160 \mathrm{~kg} \mathrm{ha}^{-1}$ of $\mathrm{N}$ and $45 \mathrm{~kg} \mathrm{ha}^{-1}$ of $\mathrm{P}$ at the end of the cycle. Nine treatments were performed resulting in a factorial arrangement of $3 \times 3$ due to the use of three doses of $\mathrm{K}$ and three doses of $\mathrm{Ca}$, expressed as follows in relation to $\mathrm{N}: \mathrm{K}: \mathrm{N}(1.8: 1.0-1.0: 1.0-0.0: 1.0)$ and Ca:N (2.0:1.0 - 1.0:1.0 - 0.0:1.0).

In order to reach these doses and equilibrate the nitrogen and ammonium $\mathrm{N}$ sources, these sources were obtained through the use of the following fertilizer combinations: Ammonium nitrate (34-0-0-0); Potassium nitrate (13-0-37-0); Calcium nitrate (15-0-0-19); Potassium chloride (0-0-50-0), Phosphoric acid (0-15-0-0) and Calcium hydroxide (0-0-0-54).

\section{Soil Analysis}

Experiments were carried out on a typical Argiudol soil type. Prior to the transplant, a soil chemical analysis was performed on a composite sample using a stainless steel tube sampler to a depth of $0.2 \mathrm{~m}$. The chemical analysis results were: $\mathrm{pH} 6.59$ (soil:water ratio 1.0:2.5); CE $0.08 \mathrm{dS}$ $\mathrm{m}^{-1}$; total N 0.147\%; active N 160 ppm (Kjeldahl); assimilable $\mathrm{P} 10$ ppm (Bray and Kurtz $\mathrm{N}^{\circ} 1$ ); $\mathrm{Ca}$ 12.15, Mg 0.31, $\mathrm{Na} 0.38$ and $\mathrm{K} 0.77$ meq 100 $\mathrm{g}^{-1}$. All exchangeable cations were determined by extraction with ammonium acetate and postdetermination of ammonium by Kjeldahl distillation using a standard method (SAGPyA, 2004). The chemical analysis of the soil indicates a level relatively rich in nitrogen, low in phosphorus, very high in $\mathrm{Ca}$ and high in $\mathrm{K}$. Considering the cations levels and particularly the sodium, together with the electric conductivity and the $\mathrm{pH}$, the experiments were carried out in a non-saline, non-sodic soil.

\section{Measurements}

In each treatment 15 fruits per repetition were taken at random during harvest. The following measurements were performed individually: i) firmness, $F(\mathrm{~kg})$; ii) pulp or mesocarp thickness, PT $(\mathrm{mm})$; iii) rind thickness, RT (mm), iv) total soluble solids concentration, TSS (\%) and; v) yield, Y (Mg ha $^{-1}$ ). 
An analog durometer, with a $\mathrm{kg}$ scale and $8 \mathrm{~mm}$ needle, was employed to measure F. Two firmness determinations were performed per fruit on their equatorial and mutually opposite planes, having previously extracted the rind with a scalpel. A digital caliber (Schwyz, 0-150 mm) was employed to measure PT and RT. The determinations of TSS were performed with a hand refractometer (Milwaukee, 0-32\%). Fruits were previously cut in halves on their equatorial planes after having determined firmness, and incisions were performed from the seed cavity to the rind. Seeds were previously extracted and a compound sample of the juice coming from the incisions was collected, employing it for the determination of TSS percent. Y was estimated considering number and mass $(\mathrm{kg})$ of the fruits in ripening stage at each experimental unit or repetition.

\section{Statistical analysis}

In the factorial experimental design for each experiment, a total area of $500 \mathrm{~m}^{2}$ was assigned. Thus, the 9 treatments and the 3 repetitions per treatment resulted in an experimental unit of $18 \mathrm{~m}^{2}$. The statistical analysis was performed with Statgraphics software applying Anova with a predetermined probability level established at 5\%.

\section{RESULTS AND DISCUSSION}

The experimental results obtained allowed us to observe that the treatments did not have a homogeneous effect on the different attributes that were measured in both varieties (Figure 1). In the pulp or mesocarp thickness, PT $(\mathrm{mm})$, a higher response to the increase of $\mathrm{K}$ was observed in 'Honey Dew Green Flesh' than in 'Sivan' (Figure 1c, d). The same was noticed when analyzing the rind, RT (mm) (Figure 1e, f). However, the measurement of the concentration of total soluble solids, TSS (\%), revealed that a higher response to the increase of K was obtained when using the cultivar 'Sivan' (Figure 1h). Firmness (F) was increased with a higher dose of K, which was more evident in 'Sivan' (Figure 1b). As regards $\mathrm{Ca}$, none of the attributes measured in both cultivars (and in absence of K) increased, except for RT, which in 'Sivan' was extremely variable in all the combinations of $\mathrm{K}-\mathrm{Ca}$ (Figure 1f). When the $\mathrm{K}: \mathrm{N}$ and $\mathrm{Ca}: \mathrm{N}$ ratios and their effect upon productivity were analysed, a positive relation between the increase of $\mathrm{K}$ and yield was observed (Figures $2 \mathrm{a}$ and $3 \mathrm{a}$ ). An increase of a unit of $\mathrm{K}$ represented a similar increase of nearly 11 $\mathrm{Mg} \mathrm{ha}^{-1}$ in both varieties. However, this relation was more consistent in the case of 'Honey Dew Green Flesh' since 95\% of the variability observed in the yield was due to the increase of $\mathrm{K}$ (Figure 2a) while in 'Sivan' there was a variability of $73 \%$ (Figure 3a). As regards $\mathrm{Ca}$, a higher $\mathrm{Ca}: \mathrm{N}$ ratio did not lead to an increase in the yield. Moreover, the equations of the adjusted lines showed negative slopes, which represented a slight decrease in yield (Figures 2b and $3 \mathrm{~b}$ ). The difference between the two varieties was that the data were better explained by the model of regression in the case of 'Honey Dew Green Flesh' (Figure 2b). In the yield analysis of the factorial combination of $\mathrm{K}$ and $\mathrm{Ca}$, the higher yields in both varieties were reached with the highest $\mathrm{K}: \mathrm{Ca}$ ratio, regardless of the concentration of $\mathrm{Ca}$ (Figure 4).

The study of the nutrient uptake curves in melon with 'Honey Dew Green Flesh revealed that the total $\mathrm{K}: \mathrm{N}$ ratio in the biomass was 1.17 and in the fruit, 1.27. In the analysis of the Ca: $\mathrm{N}$ ratio the results were 1.37 and 0.17 for the total biomass and the fruit respectively (Mendoza Cortez, Cecilio Filho, Grangeiro and Oliveira, 2014). Precisely, this latter value represents $12 \%$ of the total amount absorbed by the crop, which evidences a lower uptake of $\mathrm{Ca}$ in the fruits, in comparison with $\mathrm{K}$.

When Ca uptake from the soil is not sufficient to promote a desirable level in the fruit, sprays of $\mathrm{Ca}$ compounds is a supplemental strategy to improve its concentration in the fruit. In melon, there are several antecedents of calcium fertilization by foliar application (Bouzo and Cortez, 2012). In previous studies with others inodorous and charentais cultivars, other authors found an increase in fruit firmness (Kuti and Boehm, 1994). In another work conducted with this crop in Argentina with the $\mathrm{K}$ and $B$ application by foliar spray, an increase of TSS was obtained with B treatment (Rodriguez Torressi and Fernández, 2010). Calcium is an element in which its absorption through the fruit represents only a small amount compared with leaves (Saure, 2005) as has already been mentioned (Mendoza Cortez et al., 2014). The real effects of using higher doses of $\mathrm{Ca}$ in fertigation upon the different attributes measured in the fruit were not evident in this work. This could be observed since in the absence of potassium fertilization (0.0-2.0 and $0.0-1.0$, ratio) there was not a clear increase in the attributes measured in the fruit, except for firmness in 'Honey Dew Green Flesh' (Figure 1a).

In this regard, the following issues need to be mentioned. First, in the case of plants with a vigorous growth, generally a lower amount of $\mathrm{Ca}$ reaches the fruit (Saure, 2005). However, even though the use of $160 \mathrm{~kg} \mathrm{ha}^{-1}$ of $\mathrm{N}$ was higher than what is commonly used in Argentina, it did 
(a)

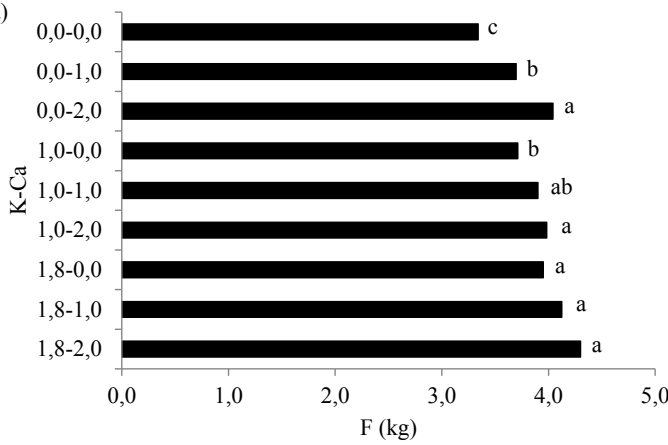

(c)

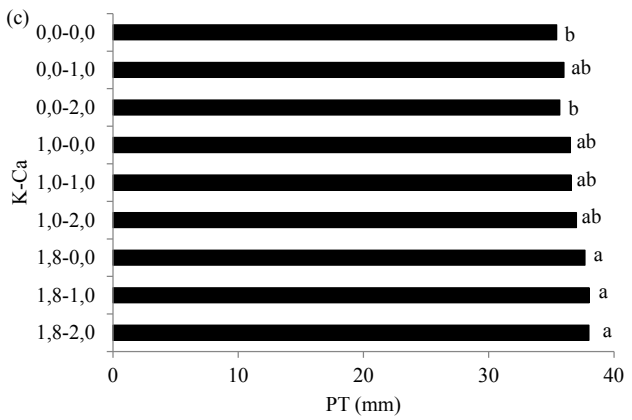

(e)

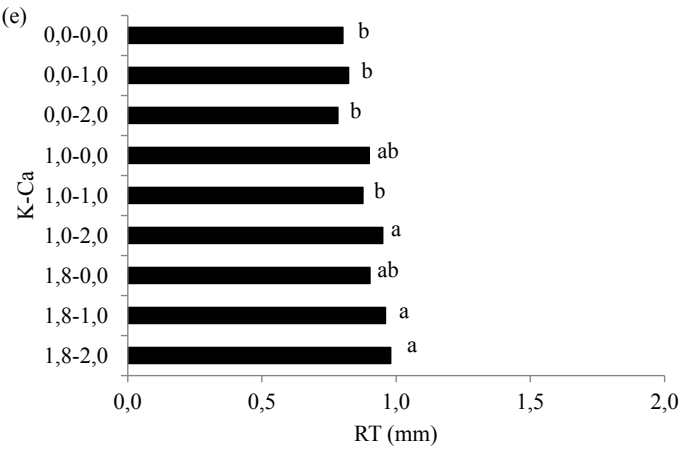

(g)

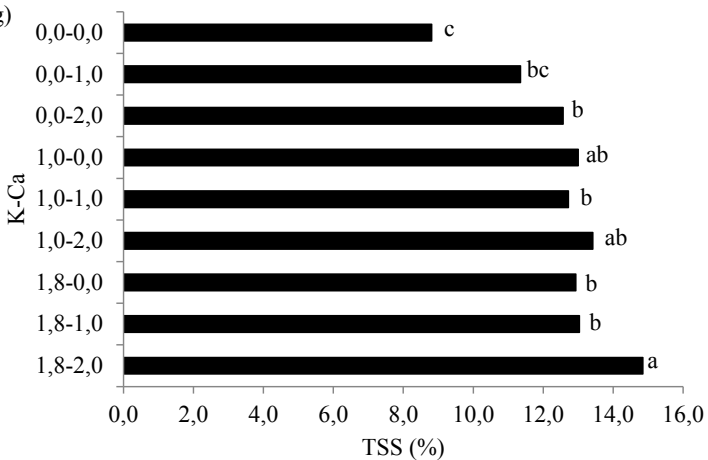

(b)

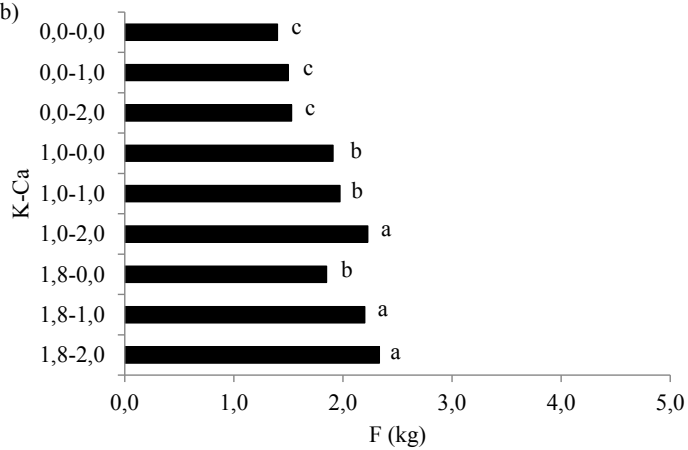

(d)

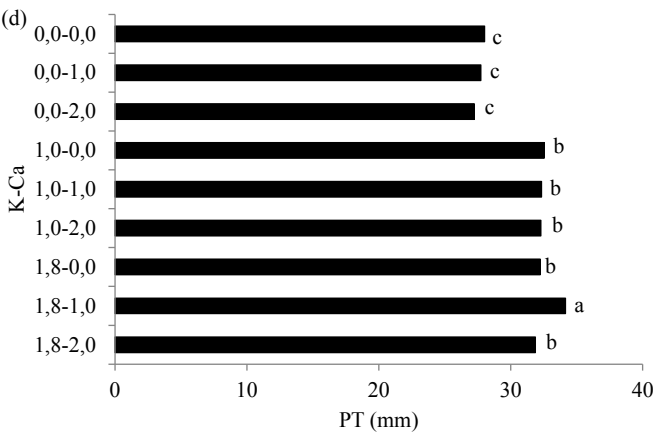

(f)

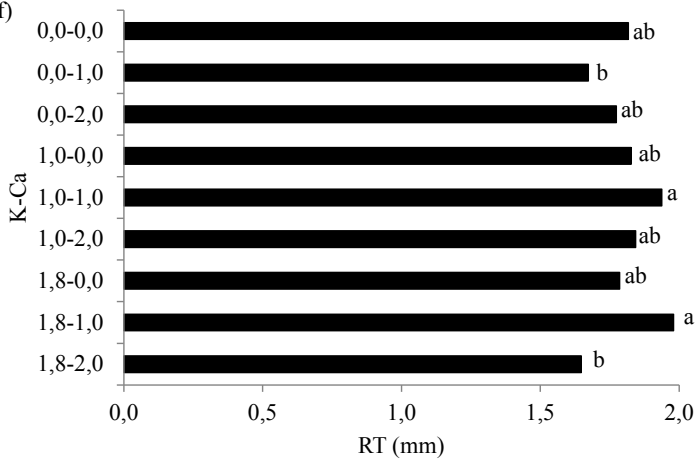

(h)

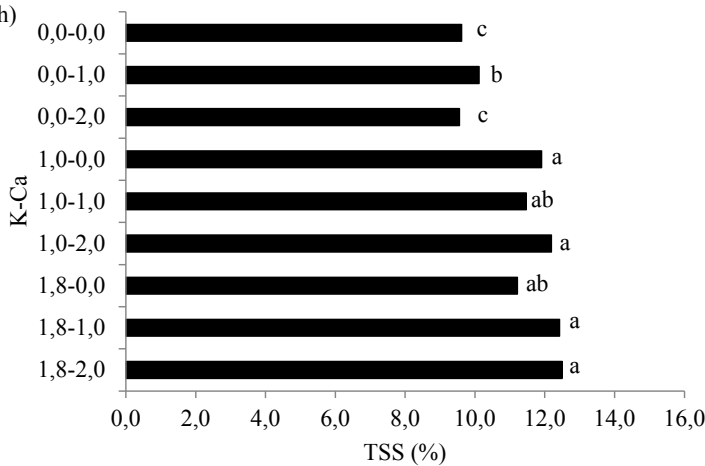

Figure 1. The effect from the factorial combination of three doses of $\mathrm{K}$ and three doses of Ca in combination with $\mathrm{N}$ upon the different quality attributes in melon fruit. The combinations of $\mathrm{K}-\mathrm{Ca}$ are presented in the ordinate axis and the values of firmness ( $\mathrm{F}$ ) ( $\mathrm{kg}$ ), pulp thickness (PT), rind thickness (RT) and total soluble solids (TSS) for both experiments with 'Honey Dew Green Flesh', (a, c, e, g) and 'Sivan', (b, d, f, h) are shown in the abscissa axis. Similar letters in each bar indicate absence of statistical differences (P $\leq$ 0.05) according to Tukey's test. 
not produce an exuberant vegetative growth (data not shown). This $\mathrm{N}$ dose has already been used by other researchers (Coelho, Sousa, Souza and Melo, 2001; Cigales-Rivero et al., 2006). Second, even though $\mathrm{Ca}$ is scarcely found in the soil, the concentration of $\mathrm{Ca}$ measured in the soil (12.15 meq $100 \mathrm{~g} \mathrm{~g}^{-1}$ ), with an apparent density of $1.3 \mathrm{~g} \mathrm{~cm}^{-3}$ and a depth of $0.30 \mathrm{~m}$, represented a theoretical availability of over $3000 \mathrm{~kg} \mathrm{ha}^{-1}$ of $\mathrm{Ca}$. The nutritional status of fruit before harvest, especially as regards $\mathrm{Ca}$, is an important factor that affects its potential storage time. Fruit with a high level of $\mathrm{Ca}$ have a lower breathing rate and a higher potential storage time than the fruit with a low level of $\mathrm{Ca}$ (Gastol and Domagala-Swiatkiewicz, 2006). The results obtained by increasing the dose of $\mathrm{Ca}$ do not allow us to assume that there was an increase in the fruit, particularly in the analysis of $\mathrm{F}$ and RT (Figure 1).

(a)

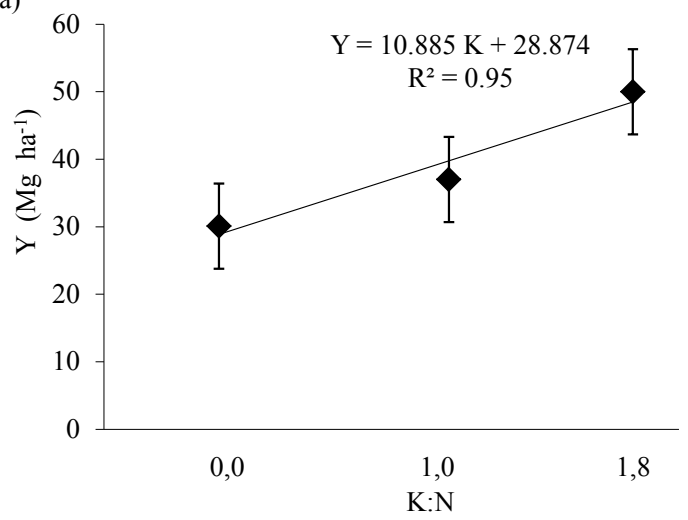

In this regard, it was observed that even with an increase in calcium fertilization, the accumulation of $\mathrm{Ca}$ in melon only occurred in leaves (Rincón Sánchez et al., 1998).

In the case of 'Sivan', $K$ happened to be the most important nutrient since when it was absent, the values of firmness were the lowest in all the $\mathrm{Ca}$ concentrations employed (Figure 1b). Firmness generally increased in the two varieties with the highest $\mathrm{K}: \mathrm{Ca}$ combined doses (1.0:2.0 and 1.8:2.0) (Figure 1a, b). The firmness in fruit was apparently more connected with the pulp or mesocarp thickness (PT) than with the pericarp or rind (RT). This assumption is mainly derived from the results obtained with 'Sivan', in which a proportional relation between the increase in firmness (Figure 1b) and the thickness of the rind (Figure 1f) was observed as a consequence of

(b)

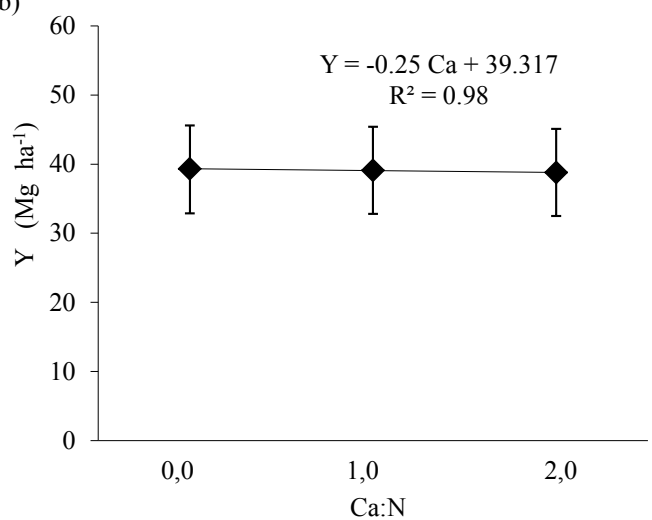

Figure 2. The effect of different ratios of potassium (a) and calcium (b) with $N\left(K: N\right.$ and Ca:N, respectively) upon yields $(Y)\left(M g\right.$ ha $\left.{ }^{-1}\right)$ in 'Honey Dew Green Flesh', LSD bars 0.05.

(a)

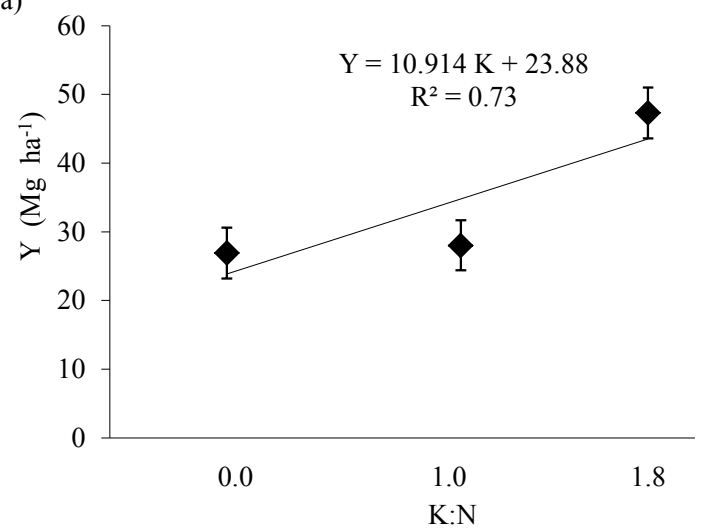

(b)

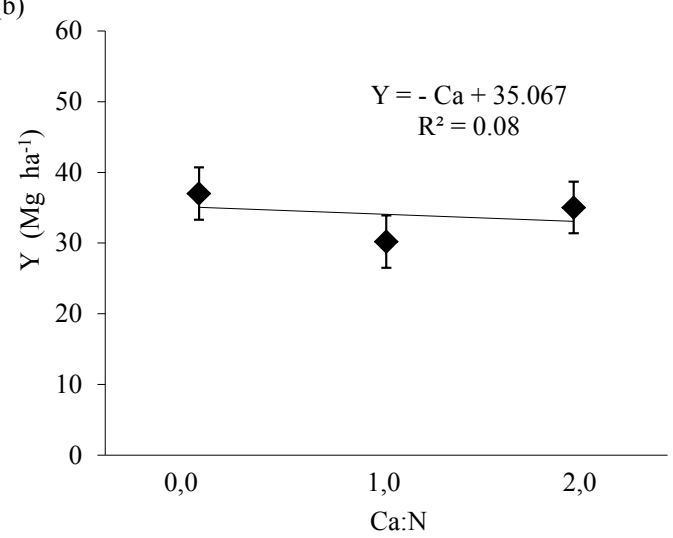

Figure 3. The effect of the different ratios of potassium (a) and calcium (b) with N (K:N and Ca: N, respectively) upon yields (Y) in 'Sivan', LSD bars 0.05 . 
(a)

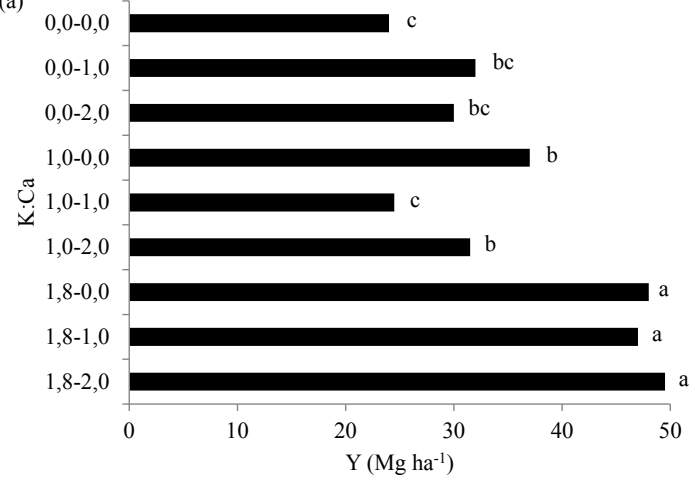

(b)

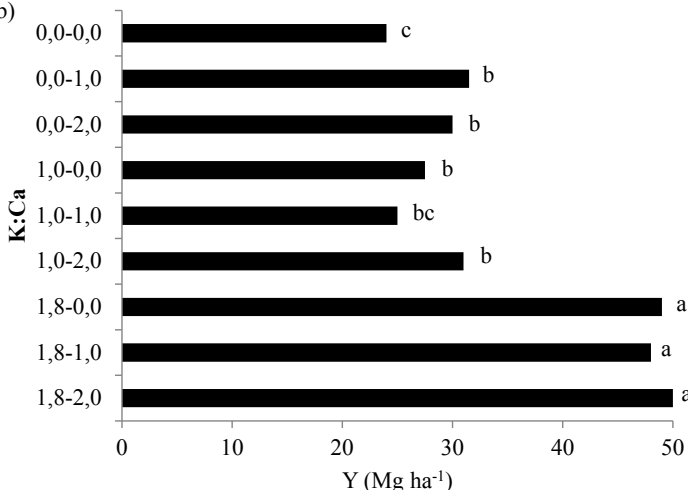

Figure 4. The effect from the factorial combination of three doses of $\mathrm{K}$ and three doses of Ca in combination with $\mathrm{N}$ (in the ordinate axis) and yields (Y), in the abscissa axis for (a), 'Honey Dew Green Flesh', and (b), 'Sivan'. Similar letters in each bar indicate absence of statistical differences $(P \leq 0.05)$ according to Tukey's test.

increasing the concentration of $\mathrm{K}: \mathrm{Ca}$. This possible relation is more evident when analyzing $\mathrm{PT}$ in the 'Sivan' since the treatments without $\mathrm{K}$ exhibited the lowest thickness (Figure 1d). Although less evident, the same tendency can also be observed in 'Honey Dew Green Flesh' (Figure 1c).

When analyzing the results of the concentration of total soluble solids (TSS) with respect to K, there was a general increase in 'Sivan' (Figure 1h). This is how, in all the treatments in which $\mathrm{K}$ was not applied, the concentration of TSS was the lowest, regardless of the concentration of $\mathrm{Ca}$.

In 'Honey Dew Green Flesh', the difference in the concentration of TSS between the treatment without $\mathrm{K}$ and $\mathrm{Ca}$ and the treatment which had the highest concentrations of these elements was great (1.8:2.0) this difference being almost $6 \%$ of TSS (Figure 1g). The highest levels of TSS were obtained in fruits with the highest concentrations of $\mathrm{K}$ and $\mathrm{Ca}$ (1.0:2.0 and 1.8:2.0). This increase in the concentration of sugars in the fruit may have been due to the role that $\mathrm{K}$ plays in the apoplastic co-transport during the sucrose charge from the mesophile to the phloem, mediated by ATPase enzymes (Le Bot et al., 1994). Other results would confirm the positive effect of a $\mathrm{K}$ increase upon the TSS of this species, as has been documented by several authors (Lin, Huang and Wang, 2004; Demiral and Köseoglu, 2005).

Most of the studies on melon have allowed determining an increase in productivity as a consequence of an increase in the $\mathrm{K}$ dose. However, there are few studies in which the joint effects of $\mathrm{N}$ and $\mathrm{K}$ have been analyzed (Coelho et al., 2001). These authors evaluated different doses of $\mathrm{N}$ and $\mathrm{K}$ through fertigation and concluded that the greatest commercial productivity (44.3 $\left.\mathrm{Mg} \mathrm{ha}^{-1}\right)$ was obtained with a combination of $160 \mathrm{~kg} \mathrm{ha}^{-1}$ of $\mathrm{N}$ and $190 \mathrm{~kg} \mathrm{ha}^{-1}$ of $\mathrm{K}_{2} \mathrm{O}$. In this way, the $\mathrm{K}: \mathrm{N}$ ratio considered as ideal as regards yellow melon yield was virtually 1.0:1.0. This value is lower than the one found in this study, in which a 1.8:1.0 ratio (Figures 2a and 3a) was obtained for yields between $45 \mathrm{Mg}$ ha $^{-1}$ and $50 \mathrm{Mg} \mathrm{ha}^{-1}$ in 'Honey Dew Green Flesh' and 'Sivan', respectively. This response to the application of a high dose of $\mathrm{K}$ is also surprising if the high concentration of $\mathrm{K}$ measured in the soil is taken into account. As regards the maximum dose of $\mathrm{K}$ used here, it was even lower than the extraction measured by Bar-Yosef (1999), a maximum extraction of $385 \mathrm{~kg} \mathrm{ha}^{-1}$ of $\mathrm{K}$. However, considering that a $\mathrm{N}$ dose like the one used here is justified by the maximum yield obtained, a K:N ratio of 1.8:1.0 is quite high taking into account the normal values for this crop, estimated at 1.33:1.0 (Bouzo et al., 2003). It may be necessary to open new lines of research with intermediate doses of $K$. This is further supported by the fact that it was found that with very high concentrations of $\mathrm{K}(>12 \mathrm{~g}$ plant $^{-1}$ of K), the TSS concentration decreased and the titratable acidity increased (Vásquez, Folegatti, Días and Sousa, 2005). In the two experiments with 'Honey Dew Green Flesh' and 'Sivan' did not observe a homogeneous effect of the application of different doses of $\mathrm{K}$ and $\mathrm{Ca}$ on the attributes of fruit quality. The increment of $\mathrm{K}$ increased pulp thickness (mesocarp) and rind (pericarp) in 'Honey Dew Green Flesh', whereas in 'Sivan' only an increase in pulp thickness was observed. The increment of $\mathrm{K}$ produced an increase of fruit firmness in both varieties, while there was a greater increase in the concentration of total soluble solids in 'Sivan'. The application of $\mathrm{Ca}$ neither produced an increase in any of the measured attributes nor in the yield 
of the two varieties used, while the application of $K$ produced an increase of yield in both cultivars with similar increase rates though with a greater variability of the mean values in 'Sivan'.

\section{REFERENCES}

Bar-Yosef, B. (1999). Advances in fertigation. Advances in Agronomy, 65, 1-77.

Bouzo, C. A., Astegiano, E. D. and Favaro, J. C. (2003). Procedimiento para predecir la necesidad de abonos en cultivos hortícolas. Revista FAVE Sección Ciencias Agrarias, 2(1-2), 7-19.

Bouzo, C. A. and Cortez, S. B. (2012). Effect of calcium foliar application on the fruit quality of melon. Revista de Investigaciones Agropecuarias (RIA), 38(3), 1-6.

Chaves, S. W. P., Aroucha, E. M. M., Pontes Filho, F. S. T., Medeiros, J. F., Souza, M. S. and Nunes, G. H. S. (2014). Conservação de melão Cantaloupe cultivado em diferentes doses de N e K. Horticultura Brasileira, 32, 468-474.

Cigales-Rivero, M. R., Pérez-Zamora, O. and PérezCastro, K. G. (2006). Efecto del nitrógeno y humedad del suelo sobre la concentración foliar de nutrimentos y rendimiento en cultivo de melón. Avances en Investigación Agropecuaria, 10(2), 57-67.

Coelho, E. F., Sousa, V. F., Souza, V. A. B. and Melo, F. B. (2001). Efeito de niveis de N e K aplicados por gotejamento na cultura do meloeiro (Cucumis melo L.) em solo arenoso. Ciência e Agrotecnologia, 25(1), 23-30.

Contreras, J. I., Plaza, B. M., Lao, M. T. and Segura, M. L. (2012). Growth and nutritional response of melon to water quality and nitrogen potassium fertigation levels under greenhouse mediterranean conditions. Communications in Soil Science and Plant Analysis, 43(1-2), 434-444.

Demiral, M. A. and Köseoglu, A. T. (2005). Effect of potassium on yield, fruit quality, and chemical composition of greenhouse-grown galia melon. Journal of Plant Nutrition, 28(1), 93-100.

Faria, C. M. B., Costa, N. D., Pinto, J. M., Brito, L. T. and Soares, J. M. (2000). Níveis de nitrogênio por fertirrigação e densidade de plantio na cultura do melão em um Vertissolo. Pesquisa Agropecuária Brasileira, 35(3), 491-495.

Gastol M. and Domagala-Swiatkiewicz, I. (2006). Effect of foliar sprays on potassium, magnesium and calcium distribution in fruits of the pear. Journal of Fruit and Ornamental Plant Research, 14(2), 169-176.

Hochmuth, G. J. (1992). Fertilizer management for dripirrigated vegetables in Florida. HortTechnology, 2, 2732.
Kuti, J. O. and Boehm, E. C. (1994). Preharvest Foliar Calcium Treatments for Reduction of Postharvest Myrothecium Fruit Rot of Muskmelon. Cucurbit Genetics Cooperative Report, 17, 78-80.

Le Bot, J., Pilbeam, D. J. and Kirkby, E. A. (1994). Plant Mineral Nutrition in Crop Production. In: A.S. Basra (Ed.). Mechanism of Plant Growth and Improved Productivity. Modern Approaches (33-72). New York: Marcel Dekker, Inc.

Lin, D., Huang, D. and Wang, S. (2004). Effects of potassium levels on fruit quality of muskmelon in soilless medium cultura. Scientia Horticulturae, 102(1), 53-60.

Mendoza Cortez, J. W., Cecilio Filho, A. B., Grangeiro, L. C. and Oliveira, F. H. T. (2014). Crecimiento, acumulación de macronutrientes y producción de melon Cantaloupo y Amarillo. Caatinga, 27(3), 72-82.

Monteiro, R. O. C., Costa, R. N. T., Silva, L. A. and Figueiredo, R. W. (2003). Efeito de níveis de irrigação e nitrogênio no teor de sólidos solúveis totais e textura de frutos de melão. Horticultura Brasileira, 21(2), 347

Oliveira, J. G. L., Laura, V. A., Biscola, H. E., Faver, S. and Dornas, M. F. (2003). Efeito da adubação potássica sobre o brix em meloeiro híbrido Red Monami. Horticultura Brasileira, 21(2), 370.

Purquerio, L. F. V. and Cecilio Filho, A. B. (2005). Concentração de nitrogênio na solução nutritiva $\mathrm{e}$ número de frutos sobre a qualidade de frutos de melão. Horticultura Brasileira, 23(3), 831-836.

Queiroga, R. C. F., Puiatti, M., Fontes, P. C. R., Cecon, P. R. and Finger, F. L. (2007). Influência de doses de nitrogênio na produtividade e qualidade do melão Cantalupensis sob ambiente protegido. Horticultura Brasileira, 25(4), 550-556

Rincón Sánchez, L. A., Sáez Sironi, J., Pérez Crespo, J. A. and Madrid, R. (1998). Growth and nutrient absorption by muskmelon crop under greenhouse. Acta Horticulturae, 458, 153-160.

Rodriguez Torressi, A. and Fernández, F. (2010). Efecto de la aplicación foliar de potasio y boro sobre el contenido de sólidos solubles totales en frutos de melón producidos en invernaderos. Horticultura Argentina, 29(70), 231.

SAGPyA. (2004). Dirección de Producción Agrícola. Sistema de Apoyo Metodológico a los Laboratorios de Análisis de Suelos (SAMLA), ISBN 987-9184-40-8, (CD-ROOM).

Saure, M. C. (2005). Calcium translocation to fleshy fruit: its mechanism and endogenous control. Scientia Horticulturae, 105, 65-89.

Silva, P. S. L., Rodrigues, V. L. P., Medeiros, J. F., Aquino, B. F. and Silva, J. (2007). Yield and quality of melon fruits as a response to the application of nitrogen and 
potassium doses. Caatinga, 20(2), 43-49.

Srinivas, K. and Prabhakar, B. S. (1984). Response of muskmelon (Cucumis melo L.) to varying levels of spacing and fertilizers. Singapore Journal of Primary Industries, 12(1), 56-61.

Valenzuela, J. L., Sanchez, A. and Romero, I. (1994). Influence of nitrogen, phosphorus, and potassium fertilization on foliar pigments in muskmelon plants. Communications in Soil Science and Plant Analysis, 25(9-10), 1595-1604.

Vásquez, M. A. N., Folegatti, M. V., Días, N. and Sousa, V. F. (2005). Qualidade pós-colheita de frutos de meloeiro fertirrigado com diferentes doses de potássio e lâminas de irrigação. Revista Brasileira de Engenharia Agrícola e Ambiental, 9(2), 199-204. 